\title{
UPAYA MENINGKATKAN HASIL BELAJAR MATEMATIKA TEMA DIRIKU MELALUI METODE PERMAINAN PAPAN SAKU SISWA KELAS I SDN 01 KURAIKECAMATAN SULIKI
}

\author{
ERVA ISMANELI \\ SDN 01 KURAI Kurai,Kecamatan Suliki,Kabupaten Lima Puluh Kota \\ erva.ismaneli85@gmail.com
}

\begin{abstract}
ABSTRAK
Penelitian ini bertujuan untuk meningkatkan upaya meningkatkan hasil belajar matematika siswa kelas SDN 01 kurai kecamatan suliki tahun pelajaran 2018/2019 dengan menggunakan metode permainan saku. Subjek dalam penelitian ini adalah siswa kelas I SDN 01 Kurai yang berjumlah 15 Orang yang terdiri 10 orang laki-laki dan 5 orang perempuan. Rata-rata hasil observasi metode permainan papan saku pada setiap sikluis yaitu : data awal (64,6\%), siklus pertama (77\%), siklus kedua (86,7\%). Hasil nilai rata-rata penilaian belajar dan jumlah siswa yang dinyatakan tuntas belajar pada setiap siklus yaitu siklus I mempunyai nilai rata-rata 77 dengan siswa yang tuntas 9 , siklus II mempunyai nilai rata-rata 87 dengan siswa yang tuntas 14 siswa. Berdasarkan angket observasi setiap siklus maka diperoleh peningkatan pada setiap siklus yaitu pada siklus I (77 \%), siklus II $(86,7 \%)$.
\end{abstract}

Kata Kunci: Permainan Papan Saku, Hasil Belajar Matematika

\section{PENDAHULUAN}

Tujuan Pendidikan Matematika menurut KTSP (2006:416) adalah : mata pelajaran Matematika perlu diberikan pada siswa mulai dari sekolah dasar, untuk membekali siswa dengan kemampuan berfikir logis, analitis, sistematis, kritis, dan kreatif, serta kemampuan kerjasama. Kompetensi tersebut diperlukan agar siswa dapat memiliki kemampuan memperoleh, mengelola, dan memanfaatkan informasi untuk bertahan hidup pada keadaan yang selalu berubah, tidak pasti, dan kompetitif.

Menciptakan suasana belajar matematika di tingkat awal yaitu di SD memerlukan sebuah pemikiran yang matangmengenai tercapainya tujuan pembelajaran, menciptakan suasana belajar yang menyenangkan dan juga menggunakan media-media konkret sebagai alat bantu pemahaman siswa.Hal ini di dukung oleh metode pembelajaran yang dikemukakan oleh J.P Dienes (Russeffendi, 2006) yaitu metode permainan.Metode permainan dalam pembelajaran matematika dapat meningkatkan motivasi belajar dengan memacu rasa tertantang diantara siswa.

Hasil belajar adalah tingkah laku yang timbul, misalnya dari yang tidak tahu menjadi tahu, timbulnya pertanyaan baru, perubahan dalam tahap kebiasaan keterampilan, kesanggupan menghargai, perkembangan sikap sosial, emosional dan pertumbuhan jasmani ( Hamalik,1990:2). Dan juga hasil belajar siswa dapat ditinjau dari beberapa aspek koknitif yaitu kemampuan siswa dalam pengetahuan (ingatan), pemahaman, penerapan (aplikasai), analisis, dan sintesis (Purwanto ,2006:18) Hasil belajar siswa juga dapat dilihat dari kemampuan siswa dalam mengingat pelajaran yang telah disampaikan guru selama proses pembelajaran, dan sebagaimana siswa tersebut untuk 
bisa menerapkan dalam kehidupan sehari-harinya, serta mampu untuk memecahkan masalah yang timbul.

Banyak hasil penelitian yang menunjukkan bahwa terdapat korelasi positif antara motivasi dan pencapaian hasil belajar, Ramadianti (2011) menunjukkan bahwa terjadi peningkatan motivasi belajar matematika yang pembelajarannya menggunakan teknik make a match, Kadir (2011) menunjukkan bahwa dengan pendekatan multiple intelligences dapat meningkatkan aktivitas belajar matematika siswa, Dwirahayu (2015) dengan kegiatan participatory action research, membantu guru memahami cara mengajar matematika dan membantu siswa memahami matematika dengan pembelajaran yang menyenangkan, selain itu mengubah pemikiran siswa yang semula tidak menyukai matematika sekarang menjadi lebih suka karena cara mengajarnya yang menyenangkan, namun menurut siswa mereka tetap banyak yang kurang mengerti dengan matematika, karena selama ini mereka belajar matematika hanya menghafal rumus dan menyelesaikan soal-soal latihan saja.

Belajar itu merupakan aktivitas baik aktivitas mental maupun aktivitas emosional. Proses pembelajaran di dalam kelas, sekalipun guru menggunakan metode ceramah akan terjadi aktivitas mental pada diri siswa, akan tetapi jika aktivitas emosionalnya tidak ada maka siswa belum dikatakan sedang belajar. Kaitannya dengan pembelajaran matematika, aktivitas matematika dapat ditunjukkan siswa dalam proses pembelajaran yang merupakan minat siswa dalam matematika( Anitah,2007)

Aktivitas matematika merupakan interpretasi dari minat siswa terhadap matematika itu sendiri. Untuk menumbuhkan minat tersebut maka pembelajaran matematika harus disajikan semenarik mungkin, misalnya (Ruseffendi, 2006) dengan menggunakan alat peraga, menggunakan permainan, teka-teki, kegiatan lapangan, kegiatan laboratorium matematika, dan lain sebagainya.

Berdasarkan hasil observasi di kelas 1 SDN 01 Kurai menunjukkan pembelajaran matematika masih di domoinasi pada guru.guru masih menggunakan metode ceramah dan latihan soal.sehingga selama proses pembelajaran siswa hanya dapat mendengarkan dan menerima pengetahuan dari guru tanpa melibatkan keaktifan anak dalam proses pembelajaran dalam memperoleh pengetahuan tersebut.Kurangnya keterlibatan siswa membuat siswa tidak aktif dalam belajar, cenderung mengantuk sehingga banyak ngobrol antar sesama siswa.

Proses pembelajaran siswa yang belum aktif dapat menyebabkan rendahnya hasil belajar siswa karena siswa hanya menjadi penerima informasi saja dengan menggunakan indera pendengaran saja. Ernest (Maulana,2012) keberhasilan semua pengajaran matematika tergantung pada keterlibatan aktif siswa, ia juga menjelaskan bahwa permainan mampu menyediakan reinforcement dan latihan keterampilan, permainan dapat memotivasi, permainan dapat membantu pemerolehan dan pengembangan konsep matematika dan melalui permainan siswa dapat mengembangkan strategi untuk pemecahan masalah.

Metode permainan di kembangkan oleh Dienes bertujuan mengarahkan dan meningkatkan pengajaran matematika dengan mengutamakan pada pengertian sehingga matematika lebih mudah untuk dipelajari dan juga lebih menarik. Selanjutnya Dienes (Somakin,2008) mengatakan bahwa matematika dianggap sebagai study tentang ilmu terstruktur, aktivitas memisah-misahkan hubungan di antara struktur- 
struktur dalam matematika dan membuat kategori atau pengelompokkan pada hubungan diantara struktur matematika, dan setiap konsep, struktur atau prinsip dalam matematika dapat disajikan dalam bentuk yang konkret sehingga lebih mudah untuk di pahami dengan baik. Oleh karena itu , peneliti mengambil Judul "upaya meningkatkan hasil belajar matematika tema diriku melalui metode permainan papan saku siswa kelas isdn 01 kurai kecamatan suliki”"

\section{METODE PENELITIAN}

Metode penelitian ini adalah PTK (Penelitian Tindakan Kelas). Penelitian ini menggunakan 2 siklus yang setiap siklus terdiri dari dua kali pertemuan. Tahapan pada setiap siklus yaitu tahap perencanaan, pelaksanaan tindakan, pengamatan dan refleksi. Populasi penelitian ini mengguankan seluruh siswa kelas 1 SDN 01 Kurai tahun pelajaran 2018/2019. Subjek penelitian ini yaitu siswa kelas 1 SDN 01 Kurai tahun pelajaran 2018/2019 yang berjumlah 15 siswa yang terdiri dari 11 siswa putra dan 4 siswa putri.

\section{HASIL DAN PEMBAHASAN}

Pelaksanaan peneltian dilakukan mulai bulan Agustus 2018 sampai dengan Oktober 2018 dengan menggunakan metode Permainan pada pembelajaran Tematik Terpadu di kelas I SDN 01 Kurai. Pembelajaran Tematik Terpadu dari setiap tindakan ini dilaksanakan dengan langkah-langkah pembelajaran dengan metode Permainan, sebelum dilaksanakan siklus ditampilkan hasil observasi awal sebagai berikut:

Tabel 1. Hasil Observasi Awal

\begin{tabular}{|l|l|c|l|}
\hline No & Nama & Nilai & Kriteria \\
\hline 1 & Kiki Oktavia & 80 & Baik \\
\hline 2 & Nabilul Akheda & 40 & Kurang \\
\hline 3 & Vinza Julianta & 100 & Sangat Baik \\
\hline 4 & Adib Azzaki Putra & 40 & Kurang \\
\hline 5 & Bayu Febrian & 80 & Baik \\
\hline 6 & Defri Ramadhan & 100 & Sangat Baik \\
\hline 7 & Delsi Junia latifah & 80 & Baik \\
\hline 8 & Fiska Mailani Putri & 80 & Baik \\
\hline 9 & Fiski Aldo Saputra & 60 & Cukup \\
\hline 10 & Hilmi Syahputra & 40 & Kurang \\
\hline
\end{tabular}




\begin{tabular}{|l|l|c|l|}
\hline 11 & M.Ilham & 90 & Sangat Baik \\
\hline 12 & Nzul Hudayani & 40 & Kurang \\
\hline 13 & Noval Fadilla Putra & 40 & Kurang \\
\hline 14 & Sakel Muazzam & 60 & Cukup \\
\hline 15 & Muhammad Syahid & 40 & Kurang \\
\hline & Jumlah & 970 & \\
\hline & Rata-rata & 64 & \\
\hline
\end{tabular}

Berdasarkan hasil observasi diatas, di peroleh data awal tentang hasil belajar siswa sebagai berikut: Siswa yang memperoleh nilai sangat baik berjumlah 3 orang dengan presentase $20 \%$. Siswa yang memperoleh nilai baik berjumlah 4 orang dengan persentase $27 \%$. Siswa yang memperoleh nilai cukup berjumlah 2 orang dengan persentase 13\%. Dan siswa yang memperoleh nilai kurang berjumlah 6 orang dengan persentase $40 \%$. Sehingga diperoleh nilai rata-rata kelas sebesar $64 \%$.

\section{Pelaksanaan Sikus I.}

Perencanaan Tindakan, Sebelum pelaksanaan tindakan menggunakan Metode Permainan Papan Saku, peneliti terlebih dahulu mempersiapkan instrumen yang akan digunakan dalam pelaksanaan tindakan. Adapun hal-hal yang peneliti lakukan antara lain: 1) Mempersiapkan rencana pelaksanaan pembelajaran (RPP) tentang materi membandingkan banyak bilangan yang akan diajarkan pada siklus I sesuai Permainan. 2) Mempersiapkan LKS yang akan digunakan dalam pelaksanaan pembelajaran. 3) Menyusun tes akhir siklus I untuk mengetahui hasil belajar setelah dilaksanakan pembelajaran menggunakan Permainan.

Pelaksanaan Tindakan Pelaksanaan siklus I dimulai pada hari Rabu 7 Agustus 2018 . Kegiatan pembelajaran dilaksanakan sesuai dengan rencana pelaksanaan yang telah disusun sebelumnya, yaitu dengan menerapkan Metode Permainan.

Pertemuan pertama pada siklus I diawali dengan pengarahan peneliti. Pada pertemuan ini, peneliti menginformasikan tujuan pembelajaran, langkah pembelajaran dengan menggunakan metode Permainan. Kemudian peneliti menjelaskan materi mengenai perbandingan banyak benda, dengan mencontohkan dengan benda yang telah disediakan. Siswa berkreasi dalam mencatat materi Perbandingan banyak benda. Catatan Permainan siswa satu sama lain berbeda tergantung kreativitasnya masingmasing. Selanjutnya siswa mengerjakan LKS yang diberikan.

Pada pertemuan kedua, siswa melakukan tanya jawab materi Perbandingan banyak benda yang telah dibahas pada pertemuan pertama. Yaitu tentang perbandingan banyak benda yang digunakan dalam merawat tubuh. Setelah itu, peneliti memberikan soal evaluasi siklus I dan meminta siswa untuk mengerjakannya. 
Untuk lebih jelasnya pelaksanaan pembelajaran diuraikan sebagai berikut: 1) Kegiatan Pendahuluan. Peneliti sebagai guru melakukan tegur sapa dengan siswa dan mempersiapkan alat tulis, buku, media pembelajaran dan meminta siswa untuk merapikan meja dan kursinya, serta meminta ketua kelas untuk menyiapkan siswa lainnya berdoa terlebih dahulu. Kemudian guru mengecek kehadiran siswa. Guru melakukan apersepsi, dan guru memotivasi siswa untuk ikut terlibat secara aktif dalam pembelajaran. 2) Kegiatan Inti. Pada kegiatan inti, proses pembelajaran dilaksanakan dengan menggunakan metode Permainan Papan Saku, dimana siswa membandingkan dua bilangan sampai dua angka dengan menggunakan kumpulan benda-benda konkret. 3) Kegiatan Penutup. Kegiatan pembelajaran yang dilakukan adalah siswa bersama guru tanya jawab tentang pembelajaran, guru memancing siswa untuk menyimpulkan pembelajaran. Sebelum menutup pembelajaran, guru memberikan reward kepada siswa yang tampil terbaik. Di akhir kegiatan siswa mengucapkan rasa syukur dengan ucapan "alhamdulillah"dan salam.

Pengamatan ( Observasi ). Dari hasil catatan lapangan, pengamatan teman sejawat dan dari hasil diskusi peneliti dengan kolaborator, maka pada siklus I ini ditemukan hal - hal berikut: 1) Kegiatan pembelajaran belum terencana dengan baik, sehingga pemakaian waktu belum efektif. 2) Suasana belajar berlangsung sangat ribut. 3) Tidak semua siswa terlihat aktif, namun ada yang hanya menyalin punya temannya. 4) Dari hasil tes secara perorangan masih banyak siswa yang mendapatkan nilai yang belum memuaskan.

Tabel 2. Aktivitas Siswa Dalam Pembelajaran Metode Permainan siklus I

\begin{tabular}{|c|l|c|c|c|c|}
\hline \multirow{2}{*}{ NO } & \multicolumn{1}{|c|}{ AKTIFITAS } & \multicolumn{3}{c|}{ JUMLAH SISWA } \\
\cline { 3 - 6 } & \multicolumn{1}{|c|}{ Aktif } & $\%$ & $\begin{array}{c}\text { Belum } \\
\text { aktif }\end{array}$ & $\%$ \\
\hline 1. & $\begin{array}{l}\text { Motivasi dan kegairahan siswa } \\
\text { dalam mengikuti pembelajaran } \\
\text { (menyelesaikan tugas mandiri) }\end{array}$ & 10 & 66.7 & 5 & 33.3 \\
\hline 2. & $\begin{array}{l}\text { Keberanian mengemukakan } \\
\text { pendapat dan bertanya }\end{array}$ & 12 & 80 & 3 & 20 \\
\hline 3. & $\begin{array}{l}\text { Partisipasi siswa dalam } \\
\text { pembelajaran }\end{array}$ & 6 & 40 & 9 & 60 \\
\hline 4. & $\begin{array}{l}\text { Kesungguhan siswa menemukan } \\
\text { hasil pengamatannya }\end{array}$ & 11 & 73.3 & 4 & 26.7 \\
\hline 5. & Keaktifan siswa & 13 & 86.6 & 2 & 13.3 \\
\hline
\end{tabular}

Refleksi, setelah dilaksanakan perencanaan dan pelaksanaan dilakukan Refleksi terhadap pembelajaran Matematika menggunakan metode Permainan. Refleksi 
merupakan analisis kendala dan permasalahan yang ditemukan di siklus I agar dalam siklus II dapat diatasi dengan perencanaan yang dapat mengatasi masalah yang ditemukan. Adapun permasalahan-permasalahan yang muncul ketika dilaksanakan tindakan siklus I antara lain. 1) Memotivasi diberikan kepada siswa saat proses PBM masih perlu ditingkatkan. 2) Guru kurang memberikan arahan dan bimbingan dalam kegiatan pembelajaran. 3) Hasil nilai yang diperoleh pada siklus I sudah semakin baik tapi masih perlu peningkatan

Adapun perhitungan nilai tes siklus 1 dan data hasil observasi dideskripsikan sebagai berikut:

Tabel 3. Rekapitulasi Hasil Pelaksanaan Siklus I

\begin{tabular}{|l|l|c|c|c|l|}
\hline No & \multicolumn{1}{|c|}{ Nama } & $\begin{array}{c}\text { Pertemuan } \\
\text { I }\end{array}$ & $\begin{array}{c}\text { Pertemuan } \\
\text { II }\end{array}$ & $\begin{array}{c}\text { Rata- } \\
\text { Rata }\end{array}$ & \multicolumn{1}{|c|}{ Kriteria } \\
\hline 1 & Kiki Oktavia & 90 & 80 & 85 & Baik \\
\hline 2 & Nabilul Akheda & 60 & 80 & 70 & Cukup \\
\hline 3 & Vinza Julianta & 100 & 90 & 95 & Sangat Baik \\
\hline 4 & Adib Azzaki Putra & 60 & 70 & 65 & Cukup \\
\hline 5 & Bayu Febrian & 80 & 90 & 85 & Baik \\
\hline 6 & Defri Ramadhan & 100 & 100 & 100 & Sangat Baik \\
\hline 7 & Delsi Junia latifah & 70 & 80 & 75 & Baik \\
\hline 8 & Fiska Mailani Putri & 80 & 90 & 85 & Baik \\
\hline 9 & Fiski Aldo Saputra & 70 & 90 & 80 & Baik \\
\hline 10 & Hilmi Syahputra & 60 & 70 & 65 & Cukup \\
\hline 11 & M.Ilham & 70 & 90 & 80 & Baik \\
\hline 12 & Nzul Hudayani & 70 & 70 & 70 & Cukup \\
\hline 13 & Noval Fadilla Putra & 50 & 60 & 55 & Kurang \\
\hline 14 & Sakel Muazzam & 90 & 80 & 85 & Baik \\
\hline 15 & Muhammad Syahid & 60 & 60 & 60 & Kurang \\
\hline & Jumlah & 1.110 & 1.200 & 1.155 & \\
\hline & Rata - Rata & 74 & 80 & 77 & \\
\hline & & & & & \\
\hline
\end{tabular}


Berdasarkan hasil observasi di atas, diperoleh hasil belajar siklus I sebagai berikut: Siswa memperoleh sangat baik sejumlah 2 orang dengan persentase $13 \%$. Siswa yang memperoleh nilai baik berjumlah 7 orang dengan persentase $43 \%$. Sedangkan siswa memperoleh nilai cukup sejumlah 4 orang dengan persentase $26 \%$, siswa memperoleh nilai kurang berjumlah 2 orang dengan persentase $13 \%$ sehingga diperoleh nilai rata-rata kelas sebesar $77 \%$.

\section{Pelaksanaan Tindakan Siklus II}

Perencanaan tindakan, sebelum pelaksanaan tindakan pada siklus 2 dengan menggunakan Metode Permainan, peneliti terlebih dahulu mempersiapkan instrumen yang akan digunakan dalam pelaksanaan tindakan. Adapun hal-hal yang peneliti lakukan antara lain: 1) Mempersiapkan rencana pelaksanaan pembelajaran (RPP) tentang materi mengidentifikasi sifat-sifat bangun ruang yang akan diajarkan pada siklus II sesuai Metode Permainan. 2) Mempersiapkan LKS yang akan digunakan dalam pelaksanaan pembelajaran. 3) Menyusun tes akhir siklus II untuk mengetahui hasil belajar setelah dilaksanakan pembelajaran menggunakan Metode Permainan. 4) Menyiapkan spidol dengan beragam warna.

Pelaksanaan Tindakan, pelaksanaan siklus II dimulai pada hari Rabu 18 September 2018 Kegiatan pembelajaran dilaksanakan sesuai dengan rencana pelaksanaan yang telah disusun sebelumnya, yaitu dengan menerapkan Permainan.

Pertemuan pertama pada siklus II diawali dengan pengarahan peneliti. Pada pertemuan ini, peneliti menginformasikan tujuan pembelajaran, langkah pembelajaran dengan menggunakan metode Permainan. Kemudian peneliti menjelaskan materi Permainan. Materi ini disampaikan dengan ceramah dan tanya jawab.

Pada pertemuan kedua, siswa diajak membuat catatan materi yang telah dibahas pada pertemuan pertama dengan Metode Permainan yang menggunakan variasi warna pada tulisan yang disajikan. Setelah itu peneliti memberikan LKS dan meminta siswa untuk menyelesaikannya. Dengan LKS yang diberikan, diharapkan siswa memahami materi yang telah disampaikan. Pada akhir pertemuan siswa diberikan soal evaluasi siklus II untuk mengetahui peningkatan hasil belajar siswa dari siklus I.

Untuk lebih jelasnya pelaksanaan pembelajaran dilaksanaan sebagai berikut: 1) Kegiatan pendahuluan. Peneliti sebagai guru melakukan tegur sapa dengan siswa dan mempersiapkan alat tulis, buku, media pembelajaran dan meminta siswa untuk merapikan meja dan kursinya, serta meminta ketua kelas menyiapkan siswa lainnya berdoa terlebih dahulu. Kemudian guru mengecek kehadiran siswa. Guru melakukan apersepsi, dalam pelaksanaan langkah ini guru memotivasi siswa untuk ikut terlibat secara aktif dalam pembelajaran.

Kegiatan inti. Pada kegiatan ini, prosess pembejaran dilaksanakan dengan menggunakan metode Permainan Papan Saku, dimana siswa menemukan cara membandingkan dua bilangan sampai dua angka dengan menggunakan benda - benda konkret.

Kegiatan penutup. Kegiatan pembelajaran yang dilakukan adalah siswa bersama guru tanya jawab tentang pembelajaran, guru memancing siswa untuk menyimpulkan pebelajaran. Sebelum menutup pembelajaran, guru memberikan reward kepada siswa 
dengan nilai yang terbaik. Di akhir kegiatan siswa mengucapkan rasa syukur dengan mengucapkan "alhamdulillah" dan membaca salam sebelum mengakhiri pembelajaran.

Observasi. Pada pertemuan kedua siklus II ini terlihat semakin jelas penguasaan siswa terhadap materi dan proses pembelajaran sudah baik. Siswa mulai menyenangi pelajaran Matematika. Semua ini terlihat dari suasana kelas yang mengembirakan. Siswa merasakan waktu untuk belajar mata pelajaran Matematika seolah-olah sedikit , karena keasyikan dalam mengikuti proses pembelajaran. Sehingga guru benar-benar berperan sebagai fasilitator dan motivator dalam proses pembelajaran.

Tabel.4 Aktivitas Siswa Dalam Pembelajaran Metode Permainan Siklus II

\begin{tabular}{|c|l|c|c|c|c|}
\hline \multirow{2}{*}{$\begin{array}{l}\mathrm{N} \\
\mathrm{O}\end{array}$} & \multicolumn{1}{|c|}{ AKTIFITAS } & \multicolumn{3}{|c|}{ JUMLAH SISWA } \\
\cline { 3 - 6 } & Aktif & $\%$ & $\begin{array}{c}\text { Belu } \\
\mathrm{m} \\
\text { aktif }\end{array}$ & $\%$ \\
\hline 1. & $\begin{array}{l}\text { Motivasi dan kegairahan siswa } \\
\text { dalam mengikuti pembelajaran } \\
\text { (menyelesaikan tugas mandiri) }\end{array}$ & 14 & 93 & 1 & 6.7 \\
\hline 2. & $\begin{array}{l}\text { Keberanian mengemukakan } \\
\text { pendapat dan bertanya }\end{array}$ & 12 & 80 & 3 & 20 \\
\hline 3. & $\begin{array}{l}\text { Partisipasi siswa dalam } \\
\text { pembelajaran }\end{array}$ & 13 & 86 & 2 & 13.3 \\
\hline 4. & $\begin{array}{l}\text { Kesungguhan siswa } \\
\text { menemukan hasil } \\
\text { pengamatannya }\end{array}$ & 14 & 93 & 1 & 6.7 \\
\hline 5. & Keaktifan siswa & 13 & 86 & 2 & 13.3 \\
\hline
\end{tabular}

Refleksi, permasalahan siswa yang sudah ada jalan keluarnya sebagai pelaksanaan refleksi, perlu diteruskan mengingat hasilnya sangat membanggakan, terutama agar prestasi belajar siswa semakin meningkat

Setelah tindakan yang dilakukan pada siklus II berakhir, peneliti dan kolaborator mengkaji kembali data yang telah diperoleh selama proses pembelajaran berlangsung. Pada siklus II ini guru lebih mendekatkan diri dengan siswa dan selalu memberikan motivasi, arahan, dan perhatian kepada siswa. Dengan cara ini, siswa menjadi tidak malu lagi untuk bertanya kepada guru maupun peneliti sehingga terjalin kedekatan antara siswa dengan guru dan peneliti.

Adapun perhitungan nilai tes siklus II dan data hasil observasi dideskripsikan sebagai berikut: 
Tabel 5. Rekapitulasi Hasil Pelaksanaan Siklus II

\begin{tabular}{|c|c|c|c|c|c|}
\hline No & Nama & $\begin{array}{c}\text { Pertemuan } \\
\text { I }\end{array}$ & $\begin{array}{c}\text { Pertemuan } \\
\text { II }\end{array}$ & $\begin{array}{l}\text { Rata- } \\
\text { Rata }\end{array}$ & Kriteria \\
\hline 1 & Kiki Oktavia & 90 & 100 & 95 & $\begin{array}{l}\text { Sangat } \\
\text { Baik }\end{array}$ \\
\hline 2 & Nabilul Akheda & 70 & 90 & 80 & Baik \\
\hline 3 & Vinza Julianta & 100 & 90 & 95 & $\begin{array}{l}\text { Sangat } \\
\text { Baik }\end{array}$ \\
\hline 4 & Adib Azzaki Putra & 70 & 90 & 80 & Baik \\
\hline 5 & Bayu Febrian & 85 & 95 & 90 & $\begin{array}{l}\text { Sangat } \\
\text { Baik }\end{array}$ \\
\hline 6 & Defri Ramadhan & 100 & 100 & 100 & $\begin{array}{l}\text { Sangat } \\
\text { Baik }\end{array}$ \\
\hline 7 & Delsi Junia latifah & 80 & 100 & 90 & $\begin{array}{l}\text { Sangat } \\
\text { Baik }\end{array}$ \\
\hline 8 & Fiska Mailani Putri & 80 & 90 & 85 & Baik \\
\hline 9 & Fiski Aldo Saputra & 80 & 100 & 90 & $\begin{array}{l}\text { Sangat } \\
\text { Baik }\end{array}$ \\
\hline 10 & Hilmi Syahputra & 70 & 90 & 80 & Baik \\
\hline 11 & M.Ilham & 75 & 95 & 85 & Baik \\
\hline 12 & Nzul Hudayani & 75 & 85 & 80 & Baik \\
\hline 13 & Noval Fadilla Putra & 70 & 70 & 70 & Cukup \\
\hline 14 & Sakel Muazzam & 100 & 100 & 100 & $\begin{array}{l}\text { Sangat } \\
\text { Baik }\end{array}$ \\
\hline 15 & Muhammad Syahid & 70 & 90 & 80 & Baik \\
\hline \multicolumn{2}{|c|}{ Jumlah } & 1.215 & 1.385 & 1.300 & \\
\hline \multicolumn{2}{|c|}{ Rata - Rata } & 81 & 92 & 87 & \\
\hline
\end{tabular}


Berdasarkan hasil observasi siklus II diatas, diperoleh hasil belajar sebagai berikut: Siswa yang memperoleh nilai yanng sangat baik berjumlah 7 orang dengan persentase $46 \%$. Siswa memperoleh nilai baik berjumlah 7 orang dengan persentase $46 \%$. Siswa dengan nilai cukup 1 orang dengan pesentase $6 \%$. Dan ditemukan tidak seorang siswapun yang memperoleh nilai kurang dengan persentase $0 \%$.

Peningkatan hasil belajar siswa pada pertemuan pertama silus II tampak dari ratarata yang diperoleh siswa yaitu 81. Setelah dilanjutkan dengan pertemuan kedua, ratarata siswa meningkat kembali menjadi 92 sehingga diperoleh nilai rata-rata siswa 87. Hasil nilai yang diperoleh dari pertemuan pertama dan kedua sudah terlihat hasil yang memuaskan sesuai dengan nilai yang diharapkan.

Dari analisis hasil belajar siswa kelas I SD Negeri 01 Kurai tampaklah bahwa prestasi siswa mengalami peningkatan dengan menggunakan metode Permainan Papan Saku. Seperti terlihat sebagai berikut:

Tabel 6. Rekapitulasi data awal, Siklus I dan Siklus II

\begin{tabular}{|l|l|l|l|l|}
\hline No & Nama & $\begin{array}{l}\text { Data } \\
\text { Awal }\end{array}$ & Siklus I & $\begin{array}{l}\text { Siklus } \\
\text { II }\end{array}$ \\
\hline 1 & Kiki Oktavia & 80 & 85 & 95 \\
\hline 2 & Nabilul Akheda & 40 & 70 & 80 \\
\hline 3 & Vinza Julianta & 100 & 95 & 95 \\
\hline 4 & Adib Azzaki Putra & 40 & 65 & 80 \\
\hline 5 & Bayu Febrian & 80 & 85 & 90 \\
\hline 6 & Defri Ramadhan & 100 & 100 & 100 \\
\hline 7 & Delsi Junia latifah & 80 & 75 & 90 \\
\hline 8 & Fiska Mailani Putri & 80 & 85 & 85 \\
\hline 9 & Fiski Aldo Saputra & 60 & 80 & 90 \\
\hline 10 & Hilmi Syahputra & 40 & 65 & 80 \\
\hline 11 & M.Ilham & 90 & 80 & 85 \\
\hline 12 & Nzul Hudayani & 40 & 70 & 80 \\
\hline 13 & Noval Fadilla Putra & 40 & 55 & 70 \\
\hline 14 & Sakel Muazzam & 60 & 85 & 100 \\
\hline 15 & Muhammad Syahid & 40 & 60 & 80 \\
\hline
\end{tabular}




\begin{tabular}{|l|l|l|l|}
\hline Jumlah & 970 & 1.155 & 1.300 \\
\hline Rata - Rata & 64 & 77 & 87 \\
\hline
\end{tabular}

Sumber hasil belajar awal siklus I dan II

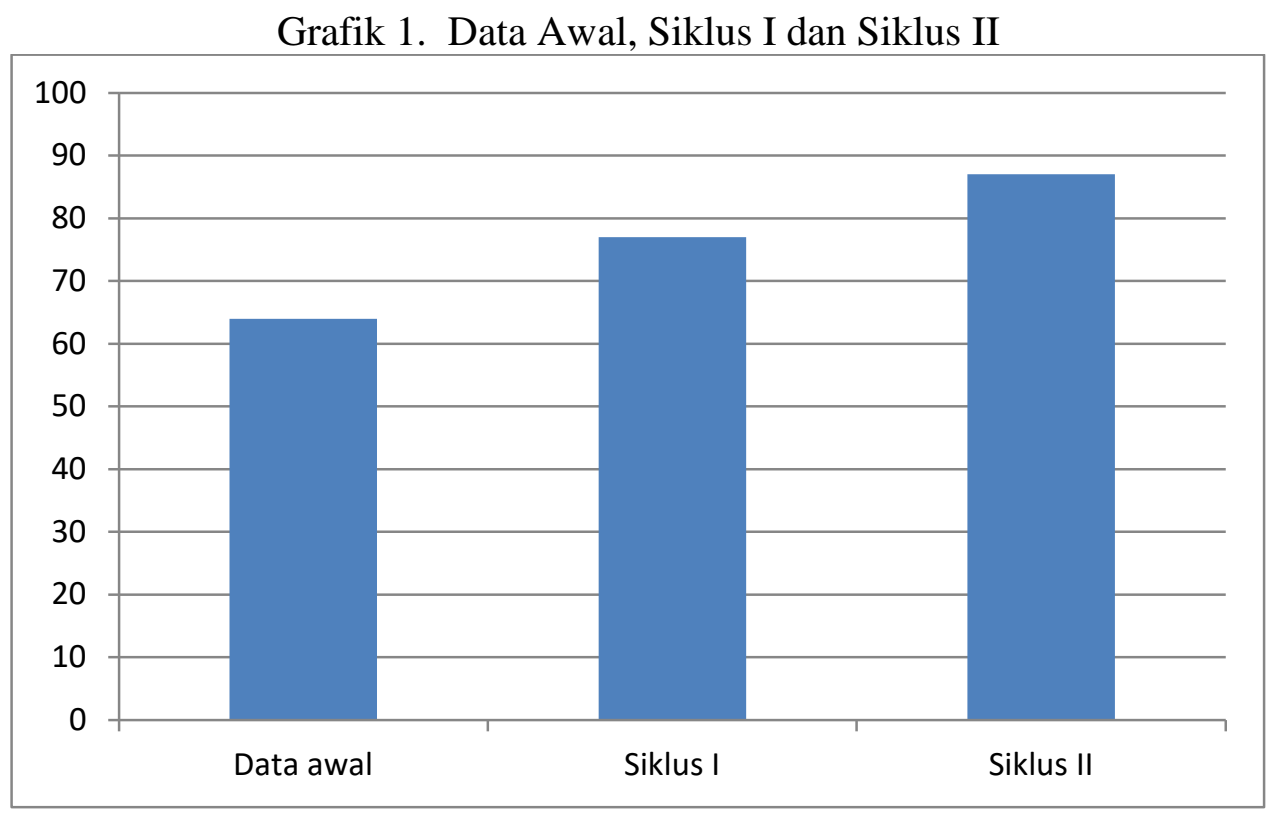

Hasil data sebelum dilaksanakan tindakan, diperoleh data nila rata-rata siswa $64 \%$ dengan kategori cukup. Setelah pembelajaran dilaksanakan dengan menggunakan metode Permainan, nilai rata-rata siswa meningkat terlihat pada siklus I dimana nilai rata-rata siswa menjadi $77 \%$ dengan kategori baik. Nilai rata-rata siswa mengalami peningkatan lagi pada siklus II dalam kategori sangat baik dengan nilai rata-rata $86 \%$.

Dengan demikian dapat disimpulkan bahwa menggunakan metode Permainan Papan Saku, dapat meningkatkan hasil belajar Matematika Tema Diriku Siswa Kelas I SD Negeri 01 Kurai Kecamatan Suliki.

\section{KESIMPULAN}

Dari uraian yang telah peneliti paparkan diatas, maka dapat disimpulkan bahwa pelaksanaan pembelajaran Tematik Terpadu dengan menggunakan metode Permainan Papan Saku dapat menciptakan kegiatan pembelajaran yang menyenangkan bagi siswa.

Hasil belajar siswa dalam pembelajaran Matematika dapat ditingkatkan melalui penggunaan metode Permainan Papan Saku . Hal ini terlihat pada hasil belajar pada awalnya $64 \%$ menjadi $77 \%$ pada siklus I, dan pada siklus II meningkat menjadi $86, \%$. Karena hasil belajar telah sesuai dengan harapan maka dapat disimpulkan bahwa penggunaan metode Permainan Papan Saku dapat meningkatkan hasil belajar Matematika Tema Diriku Siswa di kelas I SDN 01 Kurai Kecamatan Suliki.

Saran yang dapat disampaikan yaitu: (1) Guru hendaknya dapat menerapkan pembelajaran Tematik Terpadu dengan menggunakan metode Permainan Papan Saku 
sebagai salah satu alternatif dalam pembelajaran (2) Bagi instansi dan lembaga pendidik dan kependidikan sebagai bahan untuk mendukung dan menjalankan berbagai bentuk program pengembangan ilmu pendidikan.

\section{DAFTAR PUSTAKA}

Anitah, W. S., dkk., (2007) Strategi Pembelajaran di SD. Jakarta: Universitas Terbuka Dwirahayu, G., \& Diwidian, F., (2015) Upaya Meningkatkan Hasil Belajar Matematika Siswa di Madrasah Ibtidaiyah Nurun Najah 2 Rengas Ciputat Tangerang Selatan Melalui Kegiatan Partisipatory. Jurnal Pendidikan Matematika: PARADIKMA. Medan: Program Studi Pendidikan Matematika, Program Pascasarjana Universitas Negeri Medan.

Hamalik, Oemar.2008 Kurikulum dan Pembelajaran Jakarta Bumi Aksara Herumen, dkk.2007. Bahan Ajar Belajar dan Pembelajaran Padang UNP.

Heruman, (2014). Model Pembelajaran Matematika di Sekolah Dasar, Bandung: Remaja Rosdakarya

Kadir, \& Wulandari., E. (2011) Proceeding International Seminar and The Fourth National Conference on Mathematics Education: The implementation of Multiple Intelligences Based Learning to Improve students Learning activities, response, and learning outrcomes in mathematics. Yogyakarta: Dept of Mathematics Education Yogyakarta University

Kennis, J.; Mullen, R.; Tatu, J., (2010) The Math Games. Tersedia pada http://www. fredonia.edu/department/math/Methods\%202010/AMTNYS/Best\%20Math\% 20 Games\%20Ever/JennaJessBecky\%20lesson.pdf

Maulana, (2012) Berteka-teki, Bermain dan Bersenang-senang dalam Matematika. Jurnal ALGORITMA volume 7 no. 2 Desember 2012. Jakarta: CeMED UIN Syarif Hidayatullah Jakarta.

Morrison, G.S., (2012) Dasar-dasar Pendidikan Anak Usia Dini (PAUD), Jakarta: Indeks

Purwanto, Ngalim.2006.Prinsip - Prinsip dan Tekhnik Evaluasi Pengajaran. Bandung PT Remaja Rosdakarya.

Ramadianti, W., (2011) Proceeding International Seminar and The Fourth National Conference on Mathematics Education: Improving students's Motivation to Learning Math by Cooperative Learning Technique Make a Match. Yogyakarta: Dept of Mathematics Education Yogyakarta University

Rochiyati Wiraadmaja. 2000. Metodologi Penelitian Tindakan Kelas. Bandung: Rosda Karya.

Ruseffendi, H.E.T., (2006) Pengajaran Matematika Untuk Meningkatkan CBSA, Bandung: Tarsito.

Slameto, A.,(2013)Belajar dan Faktor- faktor yang Mempengaruhinnya. Jakarta: Rineka Cipta.

Somakim, (2008) Pengembangan Pembelajaran Matematika SD, Jakarta: Universitas Terbuka 